\title{
C. difficile Glutamate Dehydrogenase Measurement
}

National Cancer Institute

\section{Source}

National Cancer Institute. C. difficile Glutamate Dehydrogenase Measurement. NCI

Thesaurus. Code C150857.

The determination of the amount of glutamate dehydrogenase produced by Clostridium difficile present in a sample. 